\title{
Managing Waiting Time: Impact of Physical Environment and Interaction Quality
}

\author{
NEETU KUMARI AND SANDEEP PATYAL
}

Lecturer, Department of Commerce, Udhampur Campus, University of Jammu, India

Project fellow, University of Jammu, India

\section{Email: neetu.patyal@rediffmail.com}

Received: January 19, 2017| Revised: March 14, 2017| Accepted: March 18, 2017

Published online: April 10, 2017

The Author(s) 2017. This article is published with open access at www .chitkara.edu. in/Publications

\begin{abstract}
This Research Paper presents the key role of waiting time. This report will explore the issue associated with prolonged waiting time. Research on waiting is used to determine not only why these issues are problematic but what factors may lead them to rise. Finally research unapplied to uncover ways in which the issues can be dealt with physical environment and interaction quality. The Exploratory factor analysis and Structural Equational Modeling was used to analyse the patients of private Clinic. The study brings various waiting time filler to deal with perception management of waiting time. The study provides valuable Operational management techniques to the policymakers on the management of waiting time in Private health care sector. Both patients and staff can get benefit from reduced crowding, less complaint, positive word of mouth and satisfied patients. It also benefit the society by better health services
\end{abstract}

Keywords: Waiting Time, Physical Environment Quality, Interaction Quality, Private healthcare

\section{INTRODUCTION}

The waiting time is a critical part of service industry. Waiting for healthcare refers to any waiting period which a patient experiences before or during medical treatment. Waiting to get an appointment with a doctor, staying in a waiting room before an appointment and treatment from physician duration are different concepts in waiting for healthcare. The waiting time for patients is one of the important factors that should be considered in the management and organization of the health care system not only patient

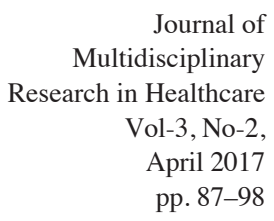

Journal of Multidisciplinary Research in Healthcare Vol-3, No-2, April 2017 pp. $87-98$ 
Kumari, $\mathrm{N}$

Patyal, $\mathrm{S}$

but also his friends and family [10]. Patients can spend longer waiting for treatment than actually receiving treatment [1]. Prompt treatment in hospitals means to minimize the time for getting a health service with an emphasis on the favorable treatment [3]. In spite of government dominance in financing healthcare in many countries, the private healthcare sector remains important. In the competitive health care service environment, patient waiting time play an important role in clinic's maintaining and attracting customers. Mackey and Cole (1997) stated that it is important to manage waiting time if organization wants to sell services. Waiting time which is the length of time from when the patient entered the waiting room or the consulting room [8] to the time the patient actually left the clinic. The present study aimed at firstly assessing patients waiting time, secondly determine the factors affecting the waiting time of patients in private clinics, thirdly, investigate waiting time filler which can influence consumer perception and suggest the managerial implication.

\section{RESEARCH PROPOSITION}

Number of Patients attend and leave the clinic at various times. The length of time a patient wait for seen, is one of the important factor affect the utilization of health services [13]. Waiting Time is a barrier to efficient patient flows in many healthcare systems. Number of researcher worked on waiting time management. Katz et al. (1991) suggested change waiting time into experienced time by "entertaining, enlightening and engaging" the consumer. Further, studies have investigated the effects of waiting-time fillers on consumer perceptions and evaluations of waiting times [12,6,14]. The study suggested two important factors physical environment quality and service interaction quality affect waiting time. The Physical environment also called service space relates to the style and appearance of the physical surroundings and other experiment elements encountered by customers at service delivery cites [7]. Physical surrounding helps to shape appropriate feeling and reaction in customers. The second important factor is service interaction quality. Interaction may include negotiations and sharing of insights in both directions. Service interaction includes a series of contact with the chosen service provider. During service interaction many customer start evaluating the quality of service they are receiving and decide whether it meets their expectation [2]. The study hypothesis that physical environment quality and service interaction quality directly and positively affect perception of Waiting time.

Hypothesis : Physical Environment Quality and Service Interaction Quality directly and positively affect perception of Waiting time. 


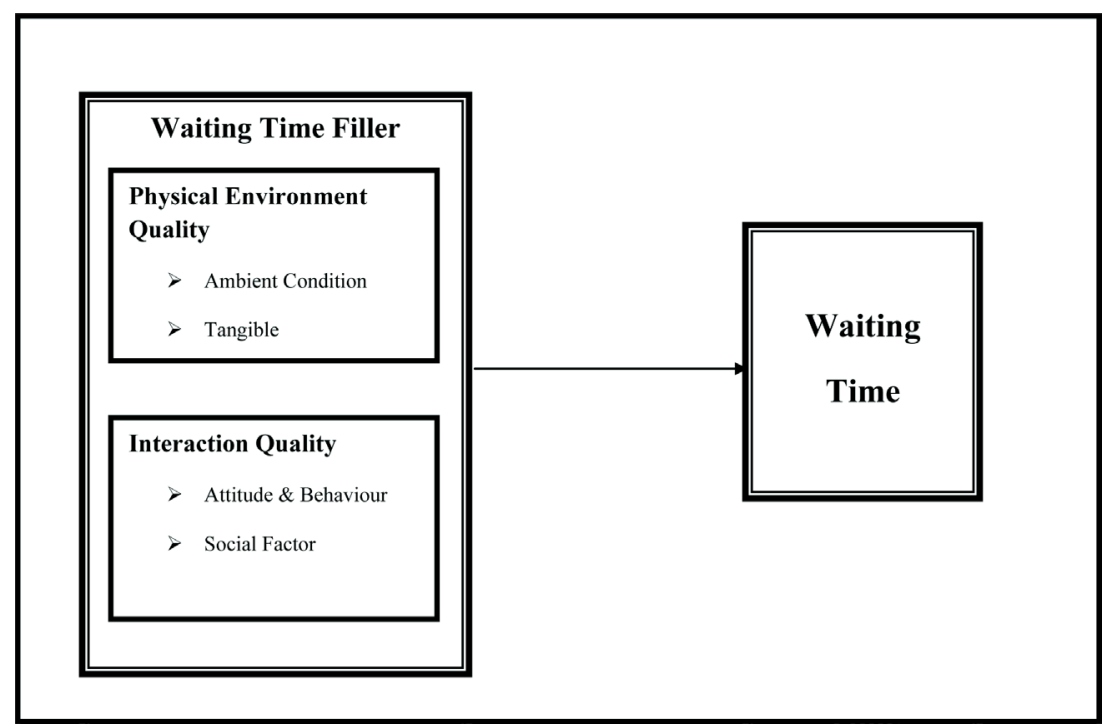

Managing Waiting

Time: Impact of Physical Environment and Interaction Quality

Figure 1: Waiting Time Model.

\section{MATERIALS AND METHODS}

The data was analyzed using descriptive statistics. Data was collected from Chopra Nursing Home Udhampur (Jammu, North India). The clinic provides service of gynecology, orthopedic, surgery and dentistry. Total number of 80 patients reported to clinic during the observation period. A non probability convenient sampling was used to select the patient reporting to emergency department. All patients attending the clinic were enlisted into the study while critically ill patients were excluded. Data was gathered using a set of comprehensive and pretested questionnaire, administered by research assistant. The questionnaire contain detail question about physical environment quality and interaction quality of the clinic that affect their waiting time perception. Respondents were asked about to fill waiting time fillers and their perception about time of waiting. The questionnaires sought such information as sociodemographic characteristics like age, sex, occupational and educational status. Other information elicited from the patients included, time spent in the waiting rooms, time spent with the doctor, causes of long waiting period and the level of satisfaction with services offered by the hospital. Satisfaction was assessed using Likert's five rating scale $(1=$ very dissatisfied, $2=$ dissatisfied, $3=$ neutral, $4=$ satisfied, $5=$ very satisfied). For the purpose of this study, the time spent in the waiting room was considered as the time the patient entered the waiting room until all the protocols leading to being registered to see the doctor 
Kumari, $\mathrm{N}$

Patyal, $\mathrm{S}$ is completed, while consulting room waiting time is from when the patient entered the consultation room and is out after history and examination by the doctor. The data was analysed with the help of Exploratory Factor Analysis.

\section{ANALYSES OF PATIENT SURVEY}

Of the 80 customer that were recruited into the study $45(56.25 \%)$ of the respondents were female. The most of the respondents fall in the range of $20-40$ $(50.00 \%)$ and $40-60(33.75 \%)$. In education wise analysis only $18.75 \%$ found to be illiterate, rest of the respondents are literate. The occupational status of the respondents showed that businessman were 25 (31.25\%), serviceman 35 (43.75 $\%$ ), retired $10(12.50 \%)$ and dependent $10(12.50 \%)$ (Table 1). The duration of waiting time in the clinic varied from 10 to 150 minute. A total of total of 15 (18.75 $\%)$ of the patients waited for less than 15 minutes, 45 (56.25\%) respondents for 15 minutes to 1 hour, $20(25.00 \%)$ respondents for more than 1 hour. Time spent with the doctor in the consultation room varied from 5 to 40 minutes, majority (31.25\%) spending 11 to 15 minutes and 16 to 20 minutes (31.25\%) with doctors. The time spent with doctor is more in dentistry and gynecology.

Table 2: Patients' Waiting Time $(\mathrm{n}=80)$.

Table 1: Socio Demographic Characteristic of Respondents $(n=80)$.

\begin{tabular}{|c|c|}
\hline \multirow[t]{2}{*}{ Demographic Characteristics } & \multirow[b]{2}{*}{ Gender } \\
\hline & \\
\hline Female & $45(56.25 \%)$ \\
\hline \multirow[t]{2}{*}{ Male } & $35(43.5 \%)$ \\
\hline & \\
\hline Below 20 yrs & $5(6.25 \%)$ \\
\hline $20-40$ yrs & $40(50.0 \%)$ \\
\hline $40-60 \mathrm{yrs}$ & $27(33.75 \%)$ \\
\hline Above 60 yrs & $8(10.0 \%)$ \\
\hline \multicolumn{2}{|c|}{ Education } \\
\hline Below 12 & $5(31.25 \%)$ \\
\hline Graduate & $30(37.5 \%)$ \\
\hline Post Graduate & $10(12.5 \%)$ \\
\hline Illiterate & $15(18.75 \%)$ \\
\hline \multicolumn{2}{|c|}{ Occupation } \\
\hline Businessman & $25(51.25 \%)$ \\
\hline Serviceman & $35(43.75 \%)$ \\
\hline Retired & $10(12.50 \%)$ \\
\hline Dependent & $10(12.50 \%)$ \\
\hline
\end{tabular}




\begin{tabular}{ll}
\hline Time Spent in Waiting Room (Minutes) & No. $(\%)$ \\
\hline Less than 15 & $15(18.75 \%)$ \\
$15-60$ & $45(56.25 \%)$ \\
Above 60 & $20(25.00 \%)$ \\
Time Spent in Consultation Room (Minutes) & \\
$5-10$ & $8(10.0 \%)$ \\
$11-15$ & $25(31.25 \%)$ \\
$16-20$ & $25(31.25 \%)$ \\
$21-25$ & $5(6.25 \%)$ \\
$26-30$ & $10(12.5 \%)$ \\
More than 30 & $7(8.75 \%)$ \\
\hline
\end{tabular}

Managing Waiting

Time: Impact of Physical

Environment and Interaction Quality

\section{DATA ANALYSIS}

A total of 17 items for Physical Environment Quality and 14 items for Interaction quality found to be useful in measuring patients perception about waiting Time. To assess the internal consistency of the items, Cronbach alpha was employed. The Cronbach's alpha for the 17 items were found to be above 0.70 . According to Hair et al. (1998), coefficient of over 0.90 would be acceptable, and generally agreed upon lower limit is 0.70 . The corrected item - total correlation was found to exceed the acceptable limit of 0.30 (Nunnally and Bernstein, 1994). Table 3 and 4, shows detail or inter - item analysis of Physical Environment and Interaction Quality Scale.

Factor Analysis was further conducted to extract useful dimension of Physical Environment and Interaction Quality Scale. The study used principal component analysis with varimax rotation. Varimax rotation being the best rotation procedure as it minimizes the number of items with high loadings on one factor, thereby enhancing the interpretability of the factors [9]. The eigen value equal to or more than 1 criterion is used to determine number of components to be extracted and KMO values equal to and greater than 0.50 is used to find out relevancy of data reduction and grouping for factor analysis. Further Bartlett test of Sphericity is used to identify correlation coefficient among the variables and degree of correlation coefficient equal to or greater than 0.30 is used as criterion for selection of items to check relationship among items [4]. The result indicate that Physical Environment Quality comprise of two factors Ambient Condition and Tangibles. Further Interaction Quality comprise of Attitude \& Behaviour and Social Factor.

Mean analysis was carried out on items of two dimensions. A mean that is equal to 3.0 indicates that the factor does have an influence much on patients' waiting time, while a mean that is less than 3.0 indicates patients' 
Kumari, $\mathrm{N}$

Patyal, $\mathrm{S}$

are dissatisfied. A mean that is greater than 4.0 indicates that the employees perceive the factor to strongly influence patients' waiting time.

\section{PHYSICAL ENVIRONMENT QUALITY}

The factor analysis carried out grouped 17 items for Physical Environment Quality (Ambient Condition $=9$ and Tangibles $=8$ ) and found to be useful in measuring patients perception about waiting Time listed in Table 3 . The 9 item collapsed and form a group namely ambient condition that influences patient perception waiting time. The respondent showed dissatisfaction specifically for unavailability of music (2.00), Duration infection (2.50), well maintained internal atmosphere (2.00) and peaceful clinic (2.50). The second important factor of physical environment quality is tangibles for which patients are specifically dissatisfied for use of computer in registration (2.00), availability of newspaper and magazines (2.00) and quick availability of test reports (2.00).

\section{INTERACTION QUALITY}

The second dimension that affects patient perception of waiting time is Interaction Quality. The Interaction quality comprise of 14 items for (Attitude $\&$ Behaviour $=7$ and Social Factor $=7$ ). The patients perceive that doctor start clinic late (2.00) which is contributing towards the problem related to Attitude and Behaviour. The final extracted factor is Social factor for which patients are specifically dissatisfied for crowed in waiting room, less spacious consultation room (2.05), clinic welcome your suggestion (2.00) and team spirit and coordinal atmosphere (1.80)

\section{FILLERS AND EVALUATION OF WAITING TIME}

The patient considers waiting as inactive, wasted or lost opportunity time [6]. Number of researcher $[12,5]$ discussed about waiting time Filler. Mcdonald, Garg and Haynes (2002) also stated that if organization cannot control the actual duration of the wait, it should consider how it might manipulate the perceived waiting time. Perceived waiting time is often different from actual waiting time. Waiting time filler that were provided in the previous studies included music [5], watching TV[12], reading Newspaper [6] etc. The study analyse the various waiting time fillers of service environment and interaction quality that can reduce perception of waiting time. Survey questionnaire was designed to know the activities the patients would like to do while they wait, Survey helped to brainstormed the list of activities. The waiting time filler come out of the study for service environment are ambient condition (music, 
Table 3: Factor Analysis on Physical Environment Quality.

\begin{tabular}{|c|c|c|c|c|}
\hline Factors & $\begin{array}{l}\text { Factor } \\
\text { Loadings }\end{array}$ & $\begin{array}{l}\text { Mean } \\
\text { Value }\end{array}$ & $\begin{array}{l}\text { Corrected } \\
\text { item-total } \\
\text { correlation }\end{array}$ & $\begin{array}{l}\text { Cronbach's } \\
\text { alpha if } \\
\text { item deleted }\end{array}$ \\
\hline $\begin{array}{l}\text { Physical Environment } \\
\text { Quality }\end{array}$ & 78.05 & & & \\
\hline Ambient Condition & $\begin{array}{l}(\mathrm{KMO}= \\
0.800 \text { Eigen } \\
\text { Value }=4.40)\end{array}$ & 3.06 & & \\
\hline Ambient Scent & 0.985 & 3.00 & 0.780 & 0.800 \\
\hline Music & 0.980 & 2.00 & 0.700 & 0.800 \\
\hline Duration Infection & 0.880 & 2.50 & 0.650 & 0.850 \\
\hline $\begin{array}{l}\text { Well maintained internal } \\
\text { atmosphere }\end{array}$ & 0.860 & 2.00 & 0.650 & 0.750 \\
\hline Cleanliness of Clinic & 0.800 & 4.00 & 0.800 & 0.750 \\
\hline Fresh air is found & 0.785 & 4.00 & 0.780 & 0.700 \\
\hline Clean Toilets & 0.700 & 4.50 & 0.850 & 0.800 \\
\hline Peaceful clinic & 0.680 & 2.50 & 0.680 & 0.800 \\
\hline Percentage of variance & 45.05 & & & \\
\hline Tangibles & $\begin{array}{l}(\mathrm{KMO}= \\
0.850 \text { Eigen } \\
\text { Value }=3.40)\end{array}$ & 2.93 & & \\
\hline $\begin{array}{l}\text { Use of Computer in } \\
\text { registration }\end{array}$ & 0.900 & 2.00 & 0.750 & 0.950 \\
\hline Patient Cards & 0.850 & 4.00 & 0.650 & 0.850 \\
\hline Television & 0.845 & 3.00 & 0.650 & 0.800 \\
\hline $\begin{array}{l}\text { Availability of Newspaper, } \\
\text { Magazines etc }\end{array}$ & 0.800 & 2.00 & 0.590 & 0.750 \\
\hline $\begin{array}{l}\text { Well furnished waiting } \\
\text { room }\end{array}$ & 0.750 & 3.40 & 0.580 & 0.700 \\
\hline $\begin{array}{l}\text { Well Equipped clinic with } \\
\text { up - to - date equipments }\end{array}$ & 0.700 & 3.00 & 0.680 & 0.705 \\
\hline Dustbin \& Spittoons & 0.700 & 4.05 & 0.750 & 0.800 \\
\hline $\begin{array}{l}\text { Test Reports are made } \\
\text { available quickly }\end{array}$ & 0.600 & 2.00 & 0.700 & 0.850 \\
\hline Percentage of variance & 33.00 & & & \\
\hline
\end{tabular}

ambient scent, sitting idle) and tangibles (watching TV, reading Newspaper,
poster, magazines cell phone, puzzles). Further the waiting time filler for
interaction quality are attitude \& behavior (attitude of frontline staff, expertise
of doctors, behavior of nurses), Social Factor (queue, talking with people). The

ambient scent, sitting idle) and tangibles (watching TV, reading Newspaper,
poster, magazines cell phone, puzzles). Further the waiting time filler for
interaction quality are attitude \& behavior (attitude of frontline staff, expertise
of doctors, behavior of nurses), Social Factor (queue, talking with people). The

ambient scent, sitting idle) and tangibles (watching TV, reading Newspaper,
poster, magazines cell phone, puzzles). Further the waiting time filler for
interaction quality are attitude \& behavior (attitude of frontline staff, expertise
of doctors, behavior of nurses), Social Factor (queue, talking with people). The

ambient scent, sitting idle) and tangibles (watching TV, reading Newspaper,
poster, magazines cell phone, puzzles). Further the waiting time filler for
interaction quality are attitude \& behavior (attitude of frontline staff, expertise
of doctors, behavior of nurses), Social Factor (queue, talking with people). The

\section{Physical Environment Quality}

Managing Waiting Time: Impact of Physical Environment and Interaction Quality 
Kumari, N

Patyal, $\mathrm{S}$

Table 4: Factor Analysis on Interaction Quality.

\begin{tabular}{|c|c|c|c|c|}
\hline Factors & $\begin{array}{l}\text { Factor } \\
\text { Loadings }\end{array}$ & $\begin{array}{l}\text { Mean } \\
\text { Value }\end{array}$ & $\begin{array}{l}\text { Corrected } \\
\text { item-total } \\
\text { correlation } \\
\end{array}$ & $\begin{array}{l}\text { Cronbach's } \\
\text { alpha if item } \\
\text { deleted }\end{array}$ \\
\hline Interaction Quality & 68.05 & & & \\
\hline Attitude and Behaviour & $\begin{array}{l}(\mathrm{KMO}= \\
0.780 \text { Eigen } \\
\text { Value }=3.50)\end{array}$ & 3.43 & & \\
\hline $\begin{array}{l}\text { Attitude and Behaviour of } \\
\text { Physicians }\end{array}$ & 0.880 & 4.50 & 0.71 & 0.88 \\
\hline $\begin{array}{l}\text { Attitude and Behaviour of } \\
\text { Nurses }\end{array}$ & 0.850 & 3.00 & 0.68 & 0.88 \\
\hline $\begin{array}{l}\text { Attitude and Behaviour of } \\
\text { Fronline staff }\end{array}$ & 0.700 & 3.00 & 0.76 & 0.88 \\
\hline Expertise of Physician & 0.680 & 4.50 & 0.75 & 0.88 \\
\hline Admission Process is simple & 0.650 & 4.00 & 0.52 & 0.88 \\
\hline Doctor Start clinic on time & 0.600 & 2.00 & 0.72 & 0.88 \\
\hline $\begin{array}{l}\text { Staff performing non related } \\
\text { duties }\end{array}$ & 0.600 & 3.00 & 0.65 & 0.88 \\
\hline Percentage of variance & 38.05 & & & \\
\hline Social Factor & $\begin{array}{l}(\mathrm{KMO}= \\
0.700 \text { Eigen } \\
\text { Value }=2.00)\end{array}$ & 2.71 & & \\
\hline Crowded Waiting Room & 0.880 & 4.05 & 0.75 & 0.80 \\
\hline Spacious Consultation Room & 0.750 & 2.05 & 0.65 & 0.80 \\
\hline Prior Appointment by Patients & 0.700 & 3.00 & 0.62 & 0.75 \\
\hline $\begin{array}{l}\text { Clinic had good impression of its } \\
\text { services on other patients }\end{array}$ & 0.705 & 4.05 & 0.60 & 0.70 \\
\hline $\begin{array}{l}\text { Sense of public responsibilities } \\
\text { among employees }\end{array}$ & 0.680 & 2.05 & 0.60 & 0.80 \\
\hline Clinic welcome your Suggestions & 0.650 & 2.00 & 0.50 & 0.85 \\
\hline $\begin{array}{l}\text { High degree of team spirit and } \\
\text { coordinal atmosphere }\end{array}$ & 0.600 & 1.80 & 0.70 & 0.70 \\
\hline Percentage of variance & 30.00 & & & \\
\hline
\end{tabular}

data gathered from customers will be used to purpose various waiting time fillers which can reduce waiting time perception. It was found that majority of patients $(16.25 \%)$ were involved in using social media on their cell phones. Further $12.5 \%$ of respondents are watching TV only 1 person showed interest in solving puzzles. Table 5 shows the different activities that the patients were doing while they were waiting. 
Table 5 : Dimension Wise: Waiting Time Filler.

\begin{tabular}{lcc}
\hline Activity & Frequency $(\mathbf{n = 8 0})$ & \% \\
\hline Ambient condition & 5 & 6.25 \\
Listening Music & 4 & 5.00 \\
Sitting Idle & & \\
Tangibles & 10 & 12.5 \\
Watching TV & 5 & 6.25 \\
Reading & 3 & 3.75 \\
Talking on Cell Phone & 8 & 10.0 \\
Playing Games & 5 & 6.25 \\
Watching Fish Pot & 1 & 1.25 \\
Solving Puzzles & 13 & 16.25 \\
Using Social Media & & \\
Attitude \& Behaviour & 4 & 5.00 \\
Waiting time information by & & \\
Frontlines staff & 5 & 6.25 \\
Patient Card & & \\
Social Factor & 8 & 6.25 \\
Talking with other patients & 5 & 5.00 \\
Talking with attendants & 4 & \\
Talking with frontline staff & &
\end{tabular}

\section{DIRECT AFFECT OF PHYSICAL ENVIRONMENT QUALITY AND INTERACTION QUALITY ON WAITING TIME}

The direct affect of Physical Environment Quality and Interaction Quality on Waiting Time is found to be significant assessed using Structural Equational Modelling (Table 6). The above 1.96 CR values revealed positive and significant effect of Ambient Condition and Tangibles on Physical Environment Quality; Attitude \& Behaviour and Social Factor on Interaction Quality. Further model fit values came out to be CMIN/DF (5.45), RMSEA (0.08), NFI (0.80), CFI (0.84). The model is considered to be fit. Hence the hypothesis is accepted.

\section{DISCUSSION AND IMPLICATIONS}

The study various identified factors perceived by patients as contributory to the long waiting time, and formulate and recommend new strategies to improve the management of waiting time. The factor analysis of Waiting Time came out with
Managing Waiting

Time: Impact of Physical Environment and Interaction Quality 
Kumari, $\mathrm{N}$

Patyal, S

Table 6 : CR, RW and SMC Physical Environment Quality and Interaction Quality on Waiting Time.

\begin{tabular}{llll}
\hline Dimensions & CR & RW & SMC \\
\hline WT $<-$ PEQ & 4.58 & 0.82 & 0.60 \\
WT $<-$ IQ & 3.59 & 0.92 & 0.56 \\
Model Fit Value & & & \\
CMIN/DF & RMSEA & NFI & CFI \\
5.45 & 0.08 & 0.80 & 0.84 \\
\hline
\end{tabular}

Note $: P E Q=$ physical environment quality, $A C=$ ambient condition, $T A N=$ tangibles, $S F$ = social factor, $I Q=$ interaction quality, $A B=$ attitude \& behaviour, $W T=$ waiting time, $C R=$ critical ratio $C M I N=$ chi square value, $D F=$ degree of freedom, $R M S E A=$ root mean square error of approximation, $N F I=$ normed fix index, $C F I=$ comparative fit index, $S R W=$ standardized egression weight

two useful dimensions Physical Environment Quality (Ambient Condition and Tangibles) and Interaction Quality (Attitude \& Behaviour and Social Factor). The study suggests two measures operational and perception management. The operational changes reduce the length of wait, like improvement in procedure of treatment, using computerized registration and availability of test reports, prior appointments and coordinal atmosphere in clinic. The second measures are manipulating the perception of waiting by waiting time fillers. The results indicate that fillers may positively effects patients perception. The results also indicate that information about expected duration through patient card also considered by patients. The activities performed by the patients before seeing the doctor can be made useful by engaging patients in activities. In this study various waiting time filler are evaluated which can manipulate the perceived waiting time like watching TV, health education program, Providing newspaper, magazine, placing educational posters, charts, having fish pot in waiting hall etc.

Inspite of government dominance in financing healthcare in many countries, the private healthcare sector remains important. This is true even though most public provision is heavily subsidized, and in many cases free, but overcrowding hospitals, fear of spreading germs, OPD for limited hour leading towards attraction of patients towards private healthcare sector. The private health care sectors are also facing problem of waiting time. The study provides valuable information to the policy-makers on the management of waiting time in Private health care sector. Both patients and staff can get benefit from reduced crowding, less complaint, positive word of mouth and satisfied patients. It also benefit the society by better health services 


\section{LIMITATION AND FUTURE RESEARCH}

The study results came out with useful findings but it is not out of some limitations. The study is limited to private clinic only. Including public hospital can bring new findings. The study only include patients perception the future research on employee view on waiting time can help in formulating more useful strategy. To measure the practical implication it is essential that in additional research suggestion given in this study should be practically implemented in clinic than perception of patient in post evaluation and after implication about waiting time should be evaluated to assess outcomes and explore applicability. The booked patient (have prior appointment), un booked patient (have no appointment) and refill patient (went directly to doctor to show test report) can be evaluated in future research.

\section{REFERENCE}

[1] Bailey, Norman T.J. (1952), "A Study of Queues and Appointment Systems in Hospital Out - Patient Departments, With Special Reference to Waiting - Times", Journal of the Royal Statistical Society, Vol. 14, No.2, 185-199.

[2] Crosby, Lawrence A., Kenneth R. Evans and Deborah Cowles (1990), "Relationship Quality in Service Selling: An Interpersonal Influence Perspective", Journal of Marketing, 54(3), 68-81. https://doi.org/10.2307/1251817

[3] Dansky K.H. and J. Miles,(1997) "Patient Satisfaction with Ambulatory Healthcare Services: Waiting Time and Filling Time", Vol. 42, No. 2, 165.

[4] Hair, J.F., R.E. Anderson, R.L. Tatham and W.C. Black, (2003), "Multivariate Data Analysis. Pearson Education" (Singapore) Private Limited. Delhi.

[5] Hui, Michael K., Laurette Dube and Jean-Charles Chebat, (1997), "The Impact of Consumers' Reaction to Waiting for Services, Journal of Retailing, Vol. 73, 87-104. https://doi.org/10.1016/S0022-4359(97)90016-6

[6] Katz, Karen L., Blaire M. Larson and Richard C. Larson (1991, Winter), "Prescription for the Waiting-in-Line Blues: Entertain, Enlighten, and Engage", Sloan Management Review, 44-53.

[7] Lovelock, Christopher, Jochen Wirtz and Jayanta Chatterjee (2010), "Services Marketing - People, Technology and Strategy". Printice Hall.

[8] Mackey TA and FL Cole (1997), "Patient Waiting Time in Nursing Managed Clinic", The International Journal of Advance Nursing Practice, Vol.1, 1.

[9] Malhotra, Naresh K. (2003), "Marketing Research - An Applied Orientation", Pearson Education (Singapore).

[10] McCarthy, L. Melissa, Ru Ding, Jesse M. Pines, Scott L. Zeger (2011), "Comparison of Methods for Measuring Crowding and its Effects on Length of
Managing Waiting

Time: Impact of Physical

Environment and Interaction Quality 
Kumari, $\mathrm{N}$

Patyal, S
Stay in the Emergency Department”, Academic Emergency Medicine, Vol. 18, No. $12,1269-1277$.

https://doi.org/10.1111/j.1553-2712.2011.01232.x PMid:22168190

[11] McDonald HP, AX Garg and RB Haynes (2002), "Interventions to Enhance Patient Adherence to Medication Prescriptions", Scientific Review, JAMA. Vol. 288, No.22, 2868-2879. https://doi.org/10.1001/jama.288.22.2868

[12] Pruyn, Ad, \& Ale. Smidts (1998), "Effects of Waiting on the Satisfaction with the Service: Beyond Objective Time Measures", International Journal of Research in Marketing, Vol.15, 321-334.

https://doi.org/10.1016/S0167-8116(98)00008-1

[13] Fernandes C, M Daya, S Barry and N Palmer (1994), "Emergency Department Patients Who Leave Without Seeing a Physician: The Toronto Hospital experience", Annual Emergency Medicine, Vol. 24, 1092-1096.

https://doi.org/10.1016/S0196-0644(94)70238-1

[14] Taylor, Shirley. (1994, April), "Waiting for Service: The relationship between Delays and Evaluations of Service. Journal of Marketing, Vol. 58, 56-69.

https://doi.org/10.2307/1252269

[15] Warren, NA (1993), "Perceived Needs of the Family Members in the Critical Care Waiting Room", Critical Care Nursing Quaterly, Vol. 16, No. 3 56-63. https://doi.org/10.1097/00002727-199311000-00009 